\title{
PROFESSIONAL INTERPRETATION IN SPORTS TRAINING - AN ANALYSIS OF THE COMMUNICATIVE PRACTICES OF VERNACULAR VIDEO ANALYSIS
}

\begin{abstract}
This paper deals with the communicative practices and expert vision. It shows that interpretation of video-recordings is not a purely cognitive, but rather an ongoing communicative accomplishment. Based on the analysis of video recordings and ethnographic research, it the analysis shows how professionals in sports training themselves use audio-visual data to generate knowledge. The analysis is based on the theoretical background of communicative constructivism and addresses the participants' use of technology, the situative bodily performance of making things visible and the local production of knowledge as a communicative practice. The specific forms exhibit the characteristics of local cultures of "vernacular video analysis". While the paper highlights the situative aspects of interpretation work it also embeds them in the wider framework of a field specific arc of work.
\end{abstract}

Keywords: visual data, vernacular video analysis, communicative practices, bodily performances, local production of knowledge

\section{Introduction}

In this paper the question how experts see and interpret visual data is scrutinized using video recordings of situations where experts themselves use and analyze video data in professional football training. The interest in the topic of practices of interpreting visual data stems on the one hand from the increasing importance of visual data within the social sciences and on the other hand in the rising importance of visual practices in contemporary society. The rising importance of the visual is described by specific terms, such as "iconic turn" (Boehm 1994) or "pictorial turn" (Mitchell 1997) and the surrounding debates highlight across disciplines the question of what role visual communication plays and whether the "visual" must be interpreted in a special way. Against this background, my research addresses the latter questions, but does not provide a mere methodological or abstract "pictorial-philosophical" approach, but embeds those topics into a framework of sociological-empirical research framed by the theory of communicative constructivism; I do address the questions as a participants' problem and investigate how those are

1 rene.tuma@tu-berlin.de 
dealt with. The practices of "seeing" and importantly "showing" are central to sociality. Knoblauch (2019) discusses this in detail on the basic example of finger pointing, with reference to Tomasello (2009). One very specific, technologically enhanced form of seeing and showing, which is currently becoming more and more present, is the use of video in everyday working contexts. It became increasingly clear to me that the medium "video", which many social scientists use to explore interactions (Heath, Hindmarsh, and Luff 2010; Knoblauch, Tuma, and Schnettler 2013), is not exclusive to the profession, but is constantly used by various practitioners in their respective fields. In other words, 'society' observes itself, much more 'concretely' than expressed with the abstract concept of observation (e.g. Luhmann 1997). Therefore during the early stages of my research I looked for experts in video analysis and found them nearly everywhere: from market researchers, sports coaches, police officers to doctors, communication coaches, etc. In all those fields, analysts scrutinize videos with varying intensity and frequency: from time to time as part of other activities or even as a full-time job. I therefore describe the dissemination of the systematic evaluation of video data in various social fields with the term "Vernacular Video Analysis". "Vernacular" in its original meaning aims at the language spoken in local contexts and/or by specific groups, but has already been transferred by Mitchell to the forms of everyday seeing that art historians have ignored (as 'vernacular seeing' Mitchell 2005:365). I have chosen this term for the paraphrase of the research object because it encompasses three important aspects of Vernacular Video Analysis:

- The specificity for the respective application context,

- The 'pragmatic' functionality as well as

- The everydayness.

I use the term Vernacular Video Analysis to describe a certain group of practices, namely the systematic evaluation of videos in the respective professional everyday life (There are similar uses of the concept, e.g. Mair et al. 2018; and with a slightly different connotation Schmidt and Wiesse 2019). The actions they consist of are not purely situational, but are specifically embedded into particular domains, which I refer to as 'fields'. I am focusing, firstly, on analyses of videos in which the actors have specifically produced or at least collected the video data in the context of their professional activities in order to evaluate it, and in which the analysis refers to the 'actions in front of the camera' (c.f. Reichertz and Englert 2010:28). Watching a film, be it on the couch in the evening or in a film analysis seminar, does not fall within my scope, because participants here do not interpret the 'natural' actions of people in front of the camera, but rather follow the crafted program for entertainment. In such cases where the produced video is in the focus of research we would therefore usually speak of film analysis rather than video analysis. Secondly, it is an activity in which the video is used to produce knowledge. While this is certainly embedded in broader contexts of action, in the process of interpreting activity the focus is on the interpretation of the video material rather than on its processing and production. This allows some further forms of the use of video to be distinguished, such as the production of live television footage in sports (Perry, Juhlin, and Engström 2014) or the editing and 
production of films (Laurier, Strebel, and Brown 2008). These activities also include aspects of the analysis activity, but do not aim at gaining knowledge, but at the film or the transmission as a product. Thirdly, video analysis, as understood here, must be distinguished from surveillance activities, in which CCTV systems are used to keep a real time (live) eye on rooms outside the field of vision, where the boundaries are fluid. These uses of video technology, which are often also embedded in coordination tasks, e.g. in control centres, have already been investigated by the Workplace Studies (Heath et al. 2002; Heath and Luff 2000; Luff, Heath, and Sanchez Svensson 2008). Those differ in that video technology is used here in a way similar to 'binoculars' or 'periscopes' and not as a 'time machine'. From my broader research, which includes also video analyses in police work and market research (Tuma 2017), the following will examine the communicative construction of interpretation with several experts using the examples of analyses in professional sports coaching.

\section{Vernacular Video Analysis in Football Training}

Analyses of tactics are increasingly finding their way into the practice of sports coaching and training. There is a wide domain of motion analysis and biomechanics (Martin 1999) that use video recordings to measure and improve the movement of individuals scientifically. Here I do focus on another tradition that focuses on team sports and the tactical analysis. Here the analysis is not so much a matter of measuring, but rather of evaluating certain game tactics, formation plans and the situational adaptation to (meaningful) moves of players in context and the opposing team. The tactical analysis itself is based on its own history, which refers to the historical development of certain playing styles and thus to knowledge specific to the sports field. Football coaches (as well as players and interested spectators) are familiar with the development of specific tactics. After all, football as a team sport is not 'only' based on the individual performance of each player, but also on a skillful lineup, on certain systems of play, which consist in certain roles of the players. Those are classified (attacker, defender, defensive or offensive midfield) and linked to certain spatial areas of the playing field (penalty area, front midfield, rear midfield, etc.). Over time, a number of typical constellations have been developed that indicate which and how many players are responsible for certain areas of the field, so they should try to control them. Historical playing systems such as the Scottish Furrow, the Russian Short Pass Game or the World Cup system have become well known during the history of football. Tactics are based on certain lineups, such as the 4-42 system (which states that four players play in defense, four in midfield and two in attack). Football history can therefore look back on a broad development in this respect (broadly presented in Wilson and Montz 2011).

In the recent past, analysts and tacticians have diagnosed a dynamization of roles, the players break away from their pre-defined positions, and a defender can, depending on the individual's abilities, be used skillfully and "push forward". 
The change of the tactical repertoire, the applied procedures and thus the tactical knowledge has become more and more relevant.

The new emphasis on tactics, adaptation to opponent's playing styles, optimization of their own lineup are becoming more dynamic, more complex and now increasingly organized by division of labor with the help of further special experts. Statistics about players - their performance in various roles and winning duels - plays a big part. The knowledge of tactical variants, their adaptation to specific teams and the experience of certain situations can be described as tactical football knowledge. There are manuals, introductions, training courses, etc., as well as specific, closely guarded secret information about concrete playing philosophies of the individual teams.

The precise tracking of all the individual players, their speed and their positions in relation to each other was very time-consuming until the 90 s without specialized computer systems.

Today professional providers of technological systems provide teams and clubs with technological infrastructure for recording games and training practices. Football stadiums are mostly equipped with high-resolution video systems which record the entire match (and sometimes also the audience) from an overview perspective and increasingly follow the individual players with automated tracking procedures. Those new systems promise automatized analysis (for a few years now) and are being established at the moment. However, at the time of my research (roughly 2014 and as far as I can estimate the following years), the traditional interpretation done by human observers prevailed (also in the video referee-context, as now established for example in the German Bundesliga).

Frequently used in the context of game and player evaluation are forms of not automatized but standardized of video-analysis, based on coding: In order to link the collected video, motion and position data with meaningful units of the game, human game observers note (tag) relevant events. This means they classify game relevant events according to a coding scheme and link it to a time code (for example, for every foul game they make a note with the minute of play, the players involved; a computer program is often used for this).

The analysis of the game is based on the one hand on the recording, archiving and provision of the video recordings in a uniform format and on the other hand on the coding and evaluation of the individual and meaningful units within the games.

The goal of universal coding of professional games is to provide a comprehensive database of the game and the players, which can be searched by means of a computer and evaluated using statistical methods. The statistical data on players and the course of the game can be used to identify the suspected strengths and weaknesses of opponents. The aggregated information and the calculated frequencies are included in the game tactics.

Besides those large scales and codings, there is another form of video analysis that is more embedded in the specific coaching of teams. This means that the interpretation is not only based on statistical data, but on reviews and reconstructions of games and training situations, and then used for coaching the teams and individual players. For 
this aim, most professional clubs (and increasingly also semi-professional teams) are equipped with devices and partly also with personnel dedicated to recording and evaluation. A specific role of a video analyst has emerged. Tasks of video analysts consist of the technical support of the teams, the recording of the matches, the preparation and provision of the recordings, as well as the selection of the sections of the entire match process relevant for training. For instance, in the English Premier League, where match analysis was early on firmly established, every club in 2013 had an average of five match analysts who, among other things, evaluate video recordings, maintain contact with sports science institutes and assist the coach (Lames 2013:41). In this area professionalization is taking place, which goes hand in hand with new academic training programs. In Germany, for example, at least two sports universities (Cologne and Munich) had started to offer special game analysis courses that also include video analysis procedures in the training with a background in sports sciences.

In this field both terms 'game analyst' and 'video analyst' are used, whereby in the typical use of the terms the former often has a strong statistical background and the latter is more concerned with the processing of the videos and the representation in the foreground. On the one hand, they bring along certain technical skills, but on the other hand they must also be very familiar with the field of football, the rules and the specific tactical knowledge. Video analysts in football are therefore mostly practically familiar with the sport themselves.

\section{Analysis as Communication}

In the case examined here, video recordings are used - in addition to the analysis of the opposing teams - above all for work in training, i.e. for reflection on the implementation of the tactics of one's own team. In the following I will go into more detail about the post-match analysis. This is embedded in the broader organisational context and the division of tasks of the football team.

The example below in this section is taken from a session that took place during a training session of a young football team (a specific selection of the best players from different clubs preparing for a future career in football). This example was taken from a training program lasting several days in which the players discussed and practiced certain techniques and tactics, in this case tactical positioning. The highlight of the training was a practice match against another (older and welltrained) team. The players were intensively coached by a staff of several coaches and additional personnel (such as physiotherapists or sports psychologists). The recording was made the morning after this game. In the room there were the younger video analyst (VA), who also recorded the game using his own technology, and the older head coach (CT). The video analyst already selected certain scenes from the game the evening before and prepared them for analysis.

In this section I describe how an interpretation of a video is made in local interaction between the participants. Based on the clips (or scenes) earlier on selected by the video analyst and the previous knowledge gained from watching 
the game, the coach and the video analyst first develop an interpretation of the event. They look for reasons why the game was lost and - prospectively for the later instruction of the players - they visit the clips where their theoretical interpretation becomes clearly visible. I will show how starting from the selection of clips in this specific football context, in the local framework of the training weekend, the video data is used to provide the players with specific training content. The training weekend follows a pre-planned work arc (Gerson 1983), which represents a part of the organisational structure of the association and contributes to the embedding in concrete communicative situations (communicative forms). The scenes are prepared and prepared against the background of both general football tactical expert knowledge as well as the knowledge of locally specific knowledge groups (names and roles of specific players, their strengths and weaknesses etc.) in order to be able to provide the players with plausible and legitimate forms of instructions and recipes for certain game situations. Selection, illustration and instruction thus each describe working steps or, in this case, concrete forms of communication embedded in this project. I will highlight the practices of interpretation in some key sequences. In the first sequences, the details of communication in the situation are explained in detail - later on, I will go into more detail about connections with the special knowledge and the specific training context.

\section{Problem Marking}

Let us start with a simple basic sequence (fragment F1a) $)^{2}$. The coach (CT, slightly older, at the back of the picture) sits together with the analyst (VA, younger, at the front of the picture) in front of a notebook. The video, played on the notebook display, is controlled by the video analyst who has previously set up the equipment, including a projector prepared for a presentation to come, opened the video analysis software and prepared the pre-selected scenes. The two of them have already watched two scenes. The video analyst has already briefly discussed this number before the beginning of the sequence shown here. Both look at the notebook in front of them and watch the video in silence. The coach (CT) understands that during the clip the video analyst (VA) sees something relevant on the video, which he confirms after a short time by moving his hand to the notebook and giving the computer the command to stop by a click.

\footnotetext{
${ }^{2}$ All transcripts have been translated from German. The QR code links to the video (in anonymized form).
} 


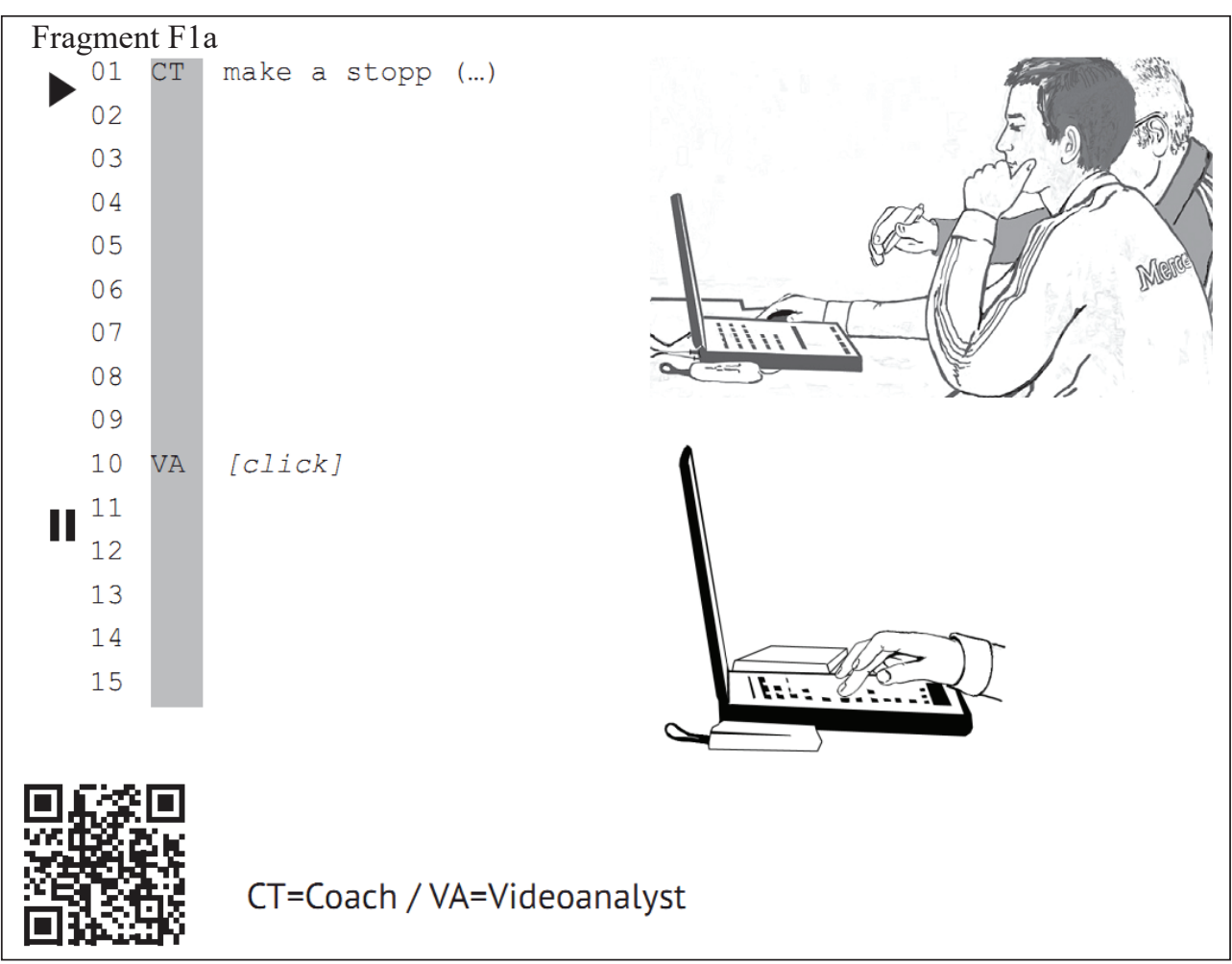

In this short sequence, in which the interpretation begins, some central features of communicative interpretation become already visible. Here we see a small communicative form of visualization: a moment in the video is selected and "shown" using the available technology. Both participants look at the picture, and indicate to each other (by focusing on the shared "perception field notebook display") that they are looking at "the same picture". As trivial as this may sound, it is a prerequisite, because the video-technology is used in a certain way, a moment in time is selected and transformed into a still image. This is also socially coordinated. The coach makes the request - the video analyst by clicking follows the request and thus a common moment is offered to both, which serves as a reference point for the following interpretation. This stopping of the video means a selection from the video that is a moving image - hence a meaningful selection, because obviously something relevant must be seen at this moment. The utterance "there" following in the second section of the sequence (Fragment $1 b$ ) then also refers to this image.

This agreement on a moment represents the first step in the viewing of something interesting for both parties, a very specific moment was chosen from the video, the coach has "provided instructions", and the video analyst made it visually available by stopping the video appropriately.

Let's continue watching the video. The coach, who is closely connected (Fragment F1b), again extends his hand forward and this time points to the screen (and not to the keys), using his pen as a pointing instrument; he identifies something 
in this visually available space of the still image that he can locate on the surface obviously the distances play a role for him. The visualization of these distances is not only a "single" act of pointing and verifying, but unfolds, as we can see in the following sequence here.

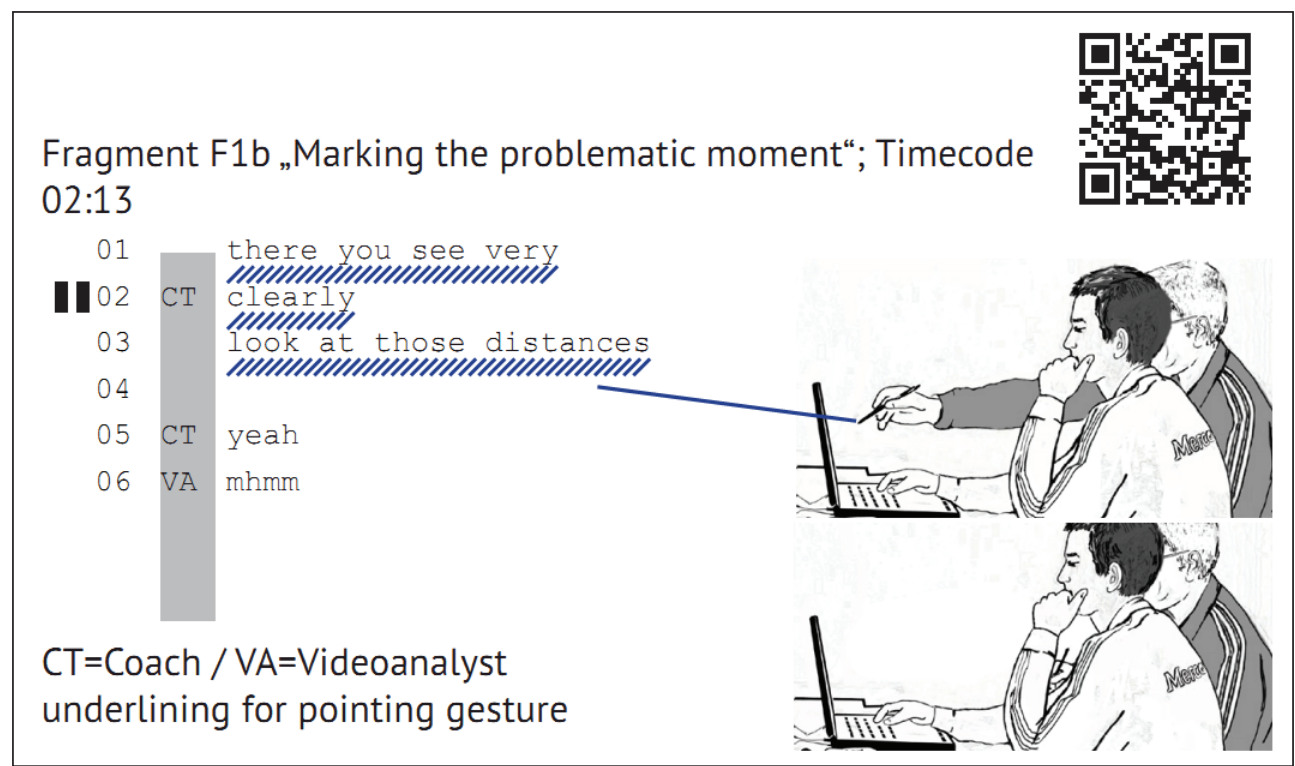

The coach pushes the pen forward and points to a specific section of the video image, to a place where something relevant is obviously visible, he also clearly emphasizes that this should also be visible to the video analyst. By "look at those distances" they are marked as knowledge, which obviously has a relevance for the analysis of the game. The coach asks the video analyst for an account of the distances that are obviously visible and interesting. After a further request by the coach ("yeah"), the video analyst hands in this confirming his account of this, not only confirming that he shares the common focus of vision, but also that he seems to recognize (or at least does not want to ask) the relevant phenomenon typified by the term distances - but without qualifying this more precisely ("mhm").

With a renewed pointing and a qualification - obviously not seeing everything - the coach continues his observation (Fragment F1c). The phenomenon that is not so easy to see - the distances that are cut off by the camera and are not in the picture - can be made interactively available on the basis of the knowledge about the events on a football field and the logical conclusion (if the players are not to be seen, they must be further back). 
Fragment F1c „Marking the problematic moment“; Timecode 02:1

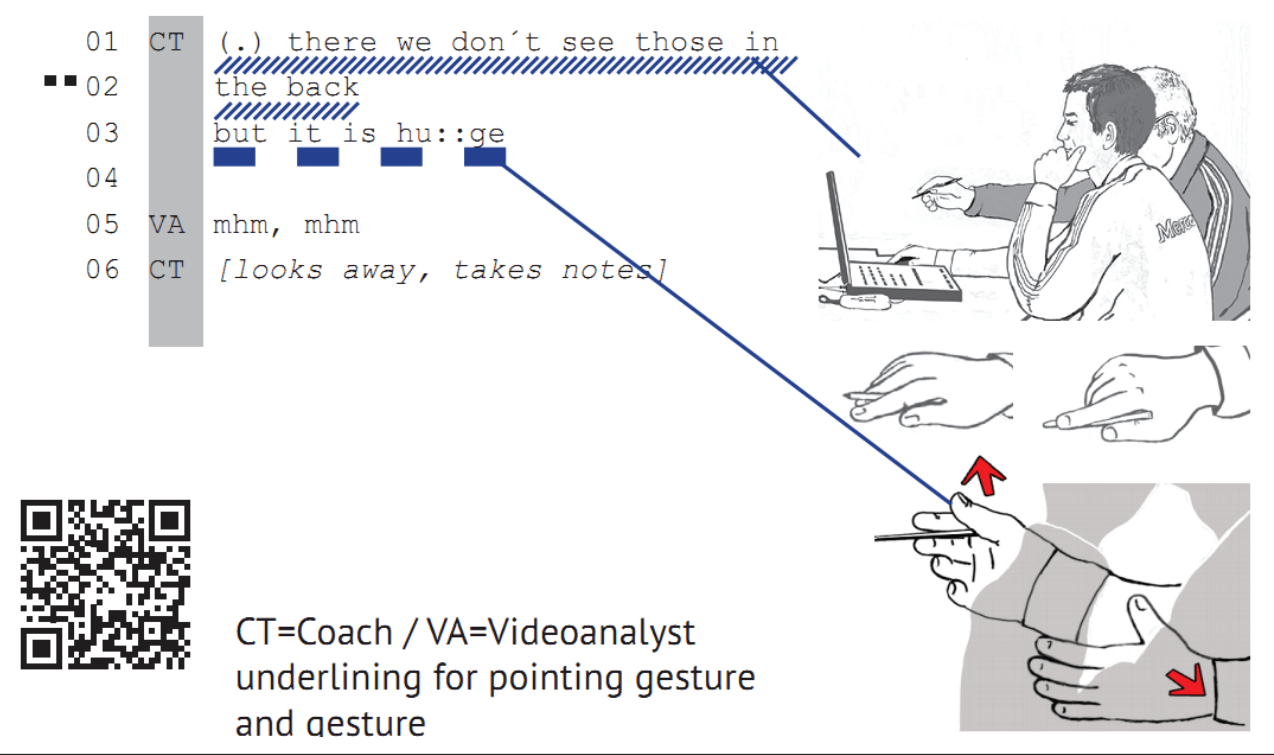

The coach achieves this on the one hand by a fine movement of the fingers - the pen first points to what is visible on the screen before gripping and pointing with the finger slightly to the right, next to the screen. The coach then performs this movement with the statement "but it is hu::ge", which he expands with a chalice-like separation of the hands (cf. Streeck, Grothues, \& Villanueva, 2009, p. 97 for a fine analysis of similar gestures connected with the deictic language). This typification of a visually available, relevant phenomenon is again confirmed by the video analyst with "mhm, mhm". Afterwards the coach turns away and writes something down - this writing down is not only an incidental writing down but he also shows that he assigns a meaning to the just produced knowledge. He keeps it on his pad and shows that he "prepares" this information for later. Furthermore, turning away from the screen and the sequence shown indicates that the work at this point is now finished - the video analyst demonstrates this by operating the computer and calling up the next scene for viewing.

The sequence showed that from the selected videos certain elements were further selected. In this case the coach first looks for a general explanation of the tactical or individual mistakes made in this (lost) game. The distances are discovered and marked as part of his argumentation - and when looking through one of the relevant sections of the game, they are made visible in the material. The specific moment in the video, which the coach selects for and with the video analyst, thus reveals a fundamental attribution of meaning. The distances - an initially abstract size, which cannot even be clearly seen on the video (the camera pans - we will go into this point later), are made relevant verbally/deictically and made available in the interaction space by means of complicated pointing gestures and the illustrative chalice gesture, hanging and unfolding, which is finely coordinated with the expression "hu::ge". The marking of distances does not only mean the visualization of a moment in video time, of a still 
image or an object, but rather the relations within the video image: here, those of the players themselves are intended. This emphasis alone is based on a specific visual knowledge, the tactical knowledge about good and correct distances, which the coach obviously possesses. Such knowledge content is partly available as theoretical knowledge coded in game philosophies and tactical game systems - but the coach does not theorize at this point, but first identifies the phenomenon, he selects it, even though there would certainly have been other aspects in the video that could have been considered. The video analyst does not just watch passively at this point - but by stopping at the right moment, by his "mhm" statements he gives the coach the opportunity to further develop the interpretation in this interaction. In these simple basic sequences, a problem was sequentially identified and linked to the theoretical concept of distances by using different pointing tools (video pause, pointing gestures with and without a pencil and "demonstrative writing"). I can show that the communicative interpretation, the viewing of such simple things as distances is based on a fine coordination of observation, the use of the computer and gestures.

\section{Troubleshooting and illustration of the consequences}

Let us look a moment later at the next sequence (Fragment F2a). Again, the video analyst ran the video or the next scene.

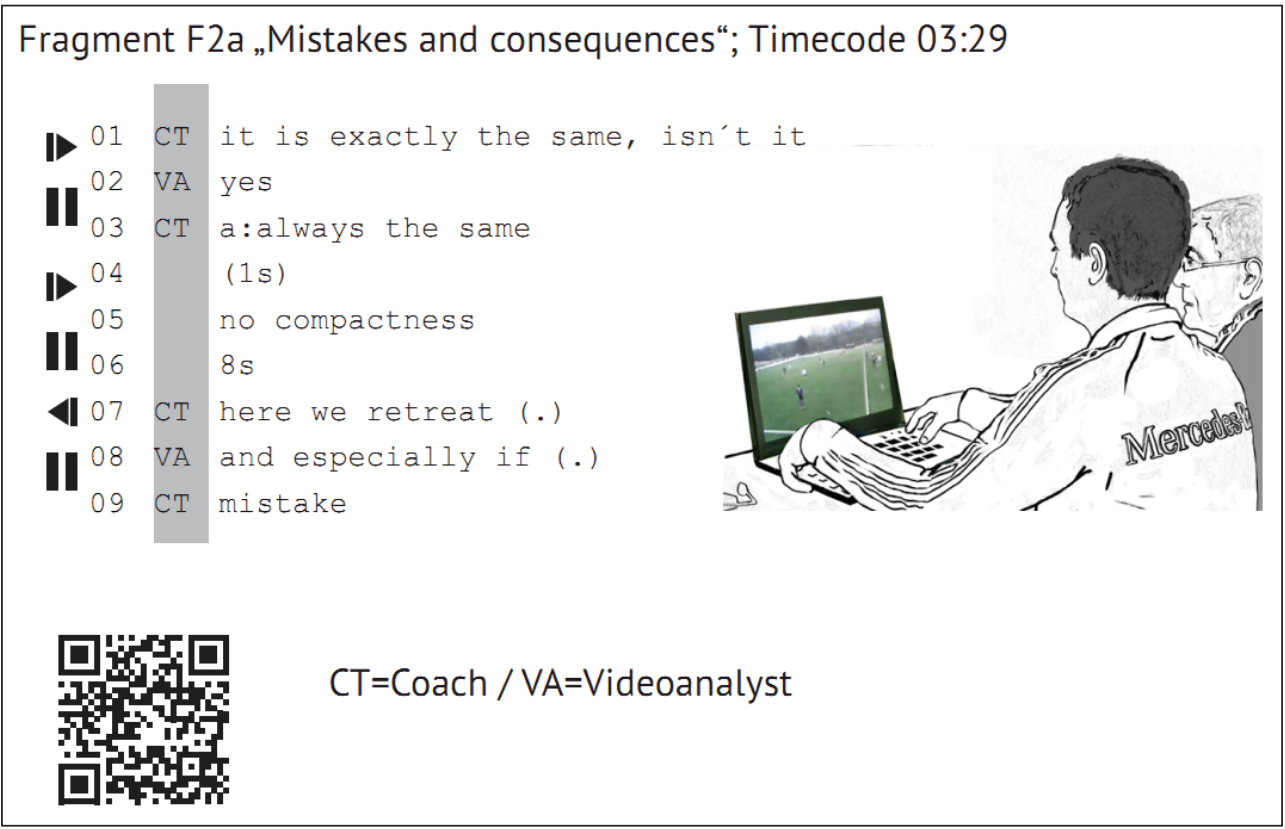

While this is still going on, the coach comments that what has just been observed (the distances) is happening again. Here, too, these seem to pose a problem - this time the video analyst also answers with a decisive "yes" to this interpretation, which he then elaborates on in more detail. The stretched "a: always the same" 
refers to a more general knowledge, the distances; respectively, the non-existent compactness of the play is a problem that he presents as already known to him. So here he has identified a recursive error pattern in the movements of the players and typified it with the term distances. The special emphasis may indicate that he had already addressed this problem during the game the day before and considers it to be one of the main reasons for the lost game. With "here we retreat" a new meaningful section in the video is identified - the withdrawing describes a change in the direction of movement of the players - and it is not directly connected logically with the distances at first. The video analyst controls the video - and stops the video several times before "here we retreat". Even before the coach utters "mistake" he rewinds some images and indicates that he too has seen something which the coach clearly categorizes as an "mistake" with the insertion before the video analyst can finish his execution, which he has already scheduled ("and especially if"). Here, "mistake" is a statement that refers to the joint knowledge of the two of them - due to their football experience and tactical knowledge, they see something in the video that is not initially formulated by themselves, but can be visualized by the consequences. Confirmed by this interjection, the video analyst plays through the possible consequences of this error - flinching at the wrong moment and too large distances in the potentials ("and if') - as an imaginary course of the situation (Fragment F2b).

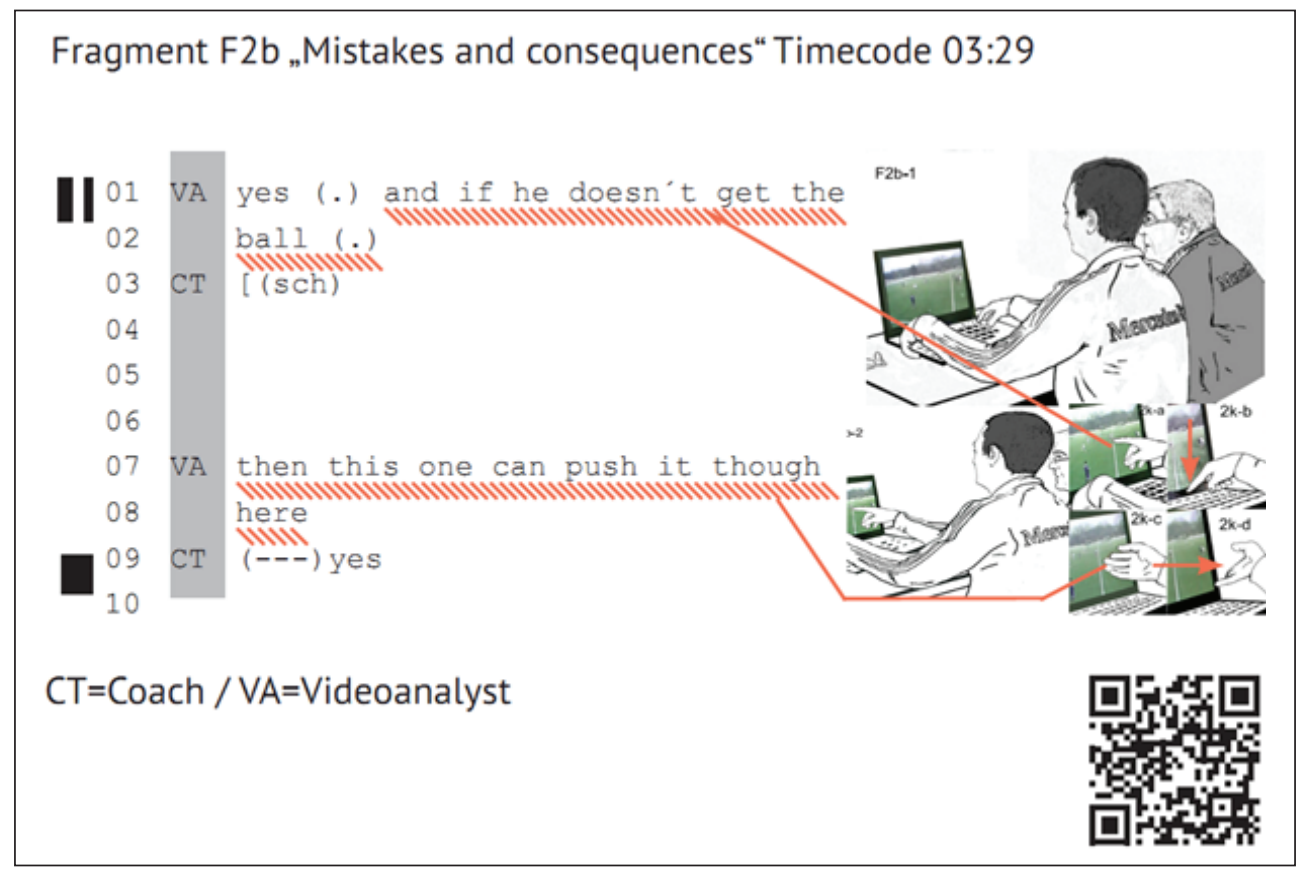

The video analyst uses a sequence of pointing gestures at individual, visible players and their possible paths or passages to develop the possible consequences of the players" "wrong" actions, using the movement of his hand to represent imaginary movements (for the analyses on movement gestures c.f. Streeck 2009:132ff). The construction of the imaginary consequences is achieved by a deictic reference to the 
video, in which certain paths of the players are set by the drawing of vectors into the space. These are not only visual or verbal, but consist of a multimodal orchestration between the selection of the relevant still image, the highlighting of dangerous opponents ("then this one can push it through") by speech and pointing gesture and the continuation through the possible gaps and paths. The coach then refers (Fragment F2c) to this construction of the error and the imagined consequences of the video analyst, thus accepting this idea.

Fragment F2c,Mistakes and consequences "Timecode 03:29

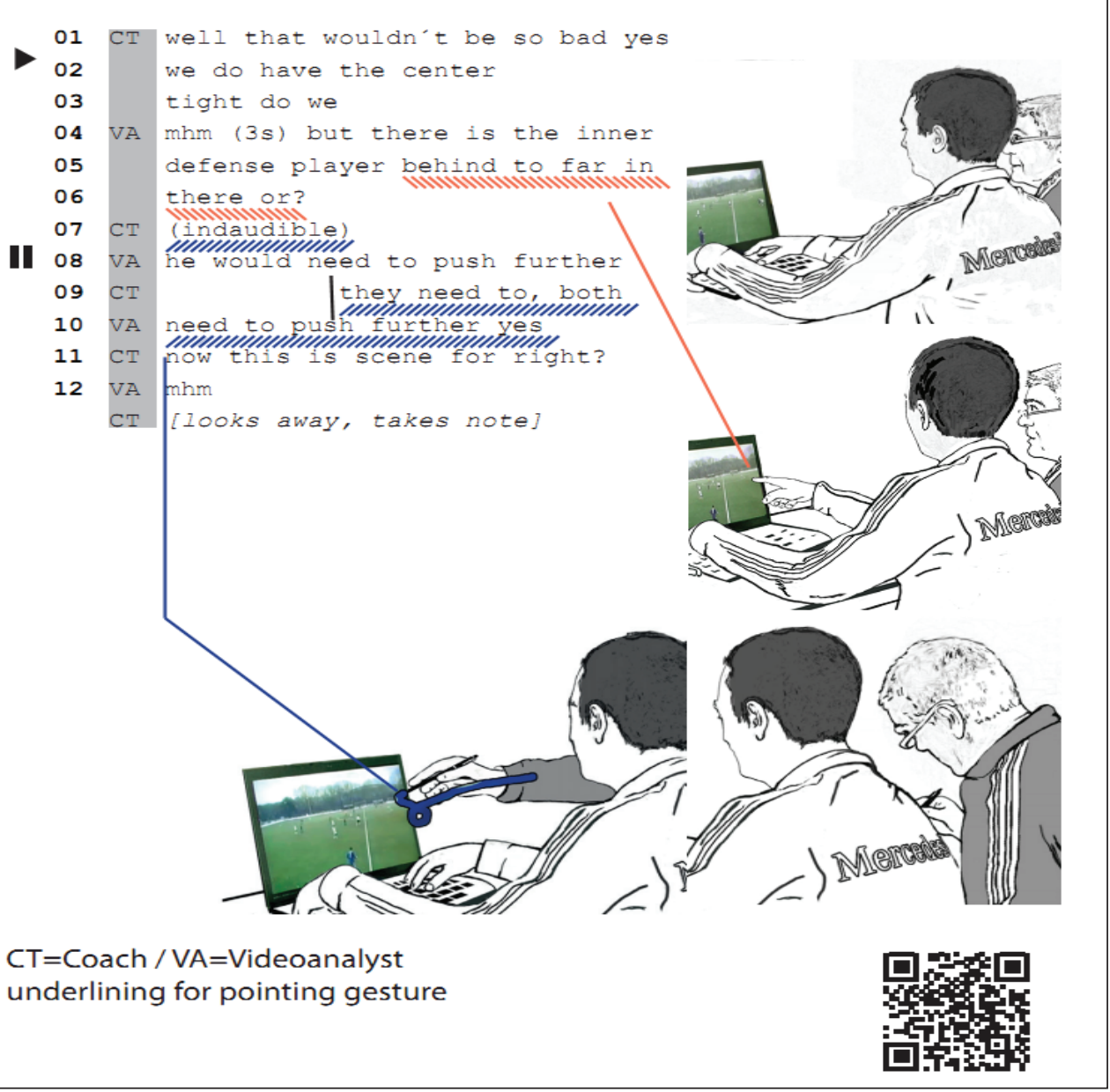

So the coach accepts the analyst's criticism of the course of the game, but limits the possible imaginary construction of how this "mistake" could have "ended". While the video is running again, he relativizes with the diagnosis that the "center" is still "tight", which describes a normative good condition, the possible scenario that the video analyst had presented.

Here the characterization of the "possible" consequences are not only aimed at a reconstruction of the respective game actions, but rather already prepared in the 
anticipation of the later instruction of the players, whereas the mistakes are to be presented and clarified in a context and with reasons.

\section{Positions and the distribution or arrangement in space}

The third treated scene begins (after some more clips have been discussed by the two of them) and now the video analyst and the coach go back again and have a closer look at their "third scene". At the beginning, the video analyst loads the video clip into the program, jumps to the beginning, waits until the coach has finished writing down the notes for the previous clip and turns to it, then starts playing, and while the video is already running, he announces the location "this is the third scene". The video is running, their own team approaches the goal from right to left. When prompted to "stop times", the video analyst will slowly reverse the video. The coach comments on the good cast at the front with strikingly deictic remarks ("there"; "up front"), which refer to a shared knowledge of the field and its practical organization.

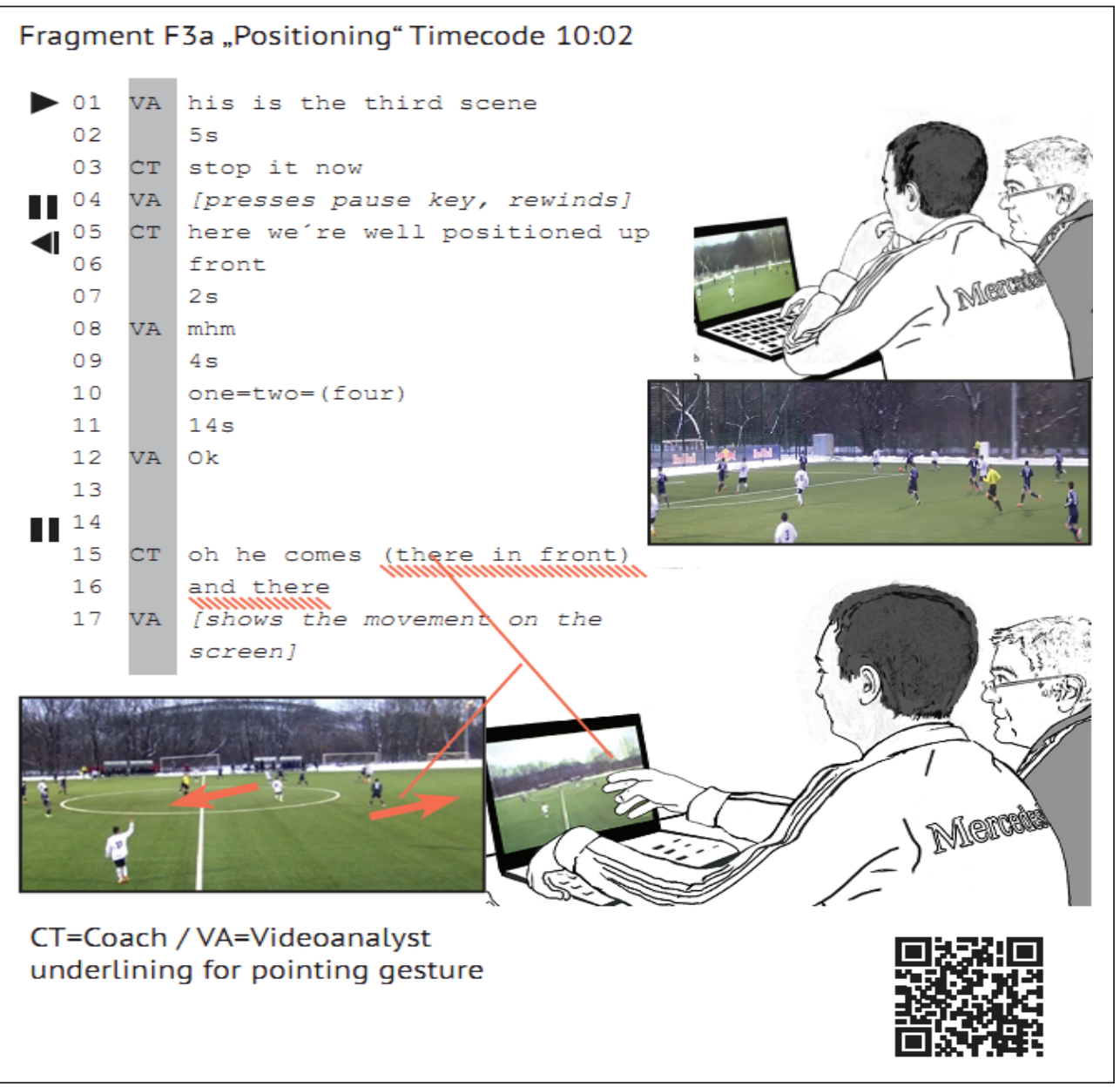


The video is slowly rewound by the video analyst on the request "stop it now" - and thus observable in the reverse - for fourteen seconds, almost to the beginning of the cut-out sequence (which begins with the winning of the ball by their own team). Both watch the video in detail and patiently wait for the slow rewind, which is also limited by the software here (the rewind with the key combination determines the speed and cannot be controlled dynamically). The reconstructions of what was seen and the statements of the coach leave an open interpretation; not a mistake is directly addressed, but first the course of events is reconstructed. The counting of the first overview of the number of players - how many "are in front in attack", how many "stay behind". The coach counts here without pointing gestures at first, but with his attention and a form of video-accompanying speech - and the consequence of the "here we're well positioned" - he makes clear what the numbers refer to: the number of players in attack. The "ok" at the end of the rewind signals that the coach has now understood the sequence for himself. This view of the clip therefore not only deals with the phenomenon of distances, which was previously seen in a still image, but rather the movement of a certain number of players in the "space to be controlled". Therefore, the interpretation here refers to the coordination of the players with each other and with the opponent - because "front" and "back" depend on the game situation. This adaptation to the dynamics of the game is not visible in an image, but over the course of time. The focus is set on the number of players, "well positioned" refers more to the number of players and less to the distances. The videoaccompanying counting of the coach makes the course character of the video visible and underpins his evaluation ("well cast") with "objective numbers", which present the statement as logical. The video, which slowly starts to fade away again, allows the video analyst to start with a reconstruction of the events - he describes and shows again with suggested vectors (this time not purely "imaginary", but with reference to the visible) from where the player comes from in possession of the ball and thus opens the exact reconstruction of the events. The coach continues the commentary on the playing action in the next fragment (F3b), directly following on from the observations of the video analyst ("e is staning up=there, everything=allright (.) lets him play") and classifies them. In this section, it became particularly clear that two experts familiar with the respective case are dealing with the video, and that they can therefore communicate with each other with very brief statements referring to shared understanding before a shared special knowledge of both football tactics and the actual game. The slow rewind with a description of what has been seen initially leaves a space for interpretation open, which is filled with an evaluation and problem marking in the directly following sequence, so that the actors themselves search here 
Fragment F3b „Positioning“; Timecode 10:02

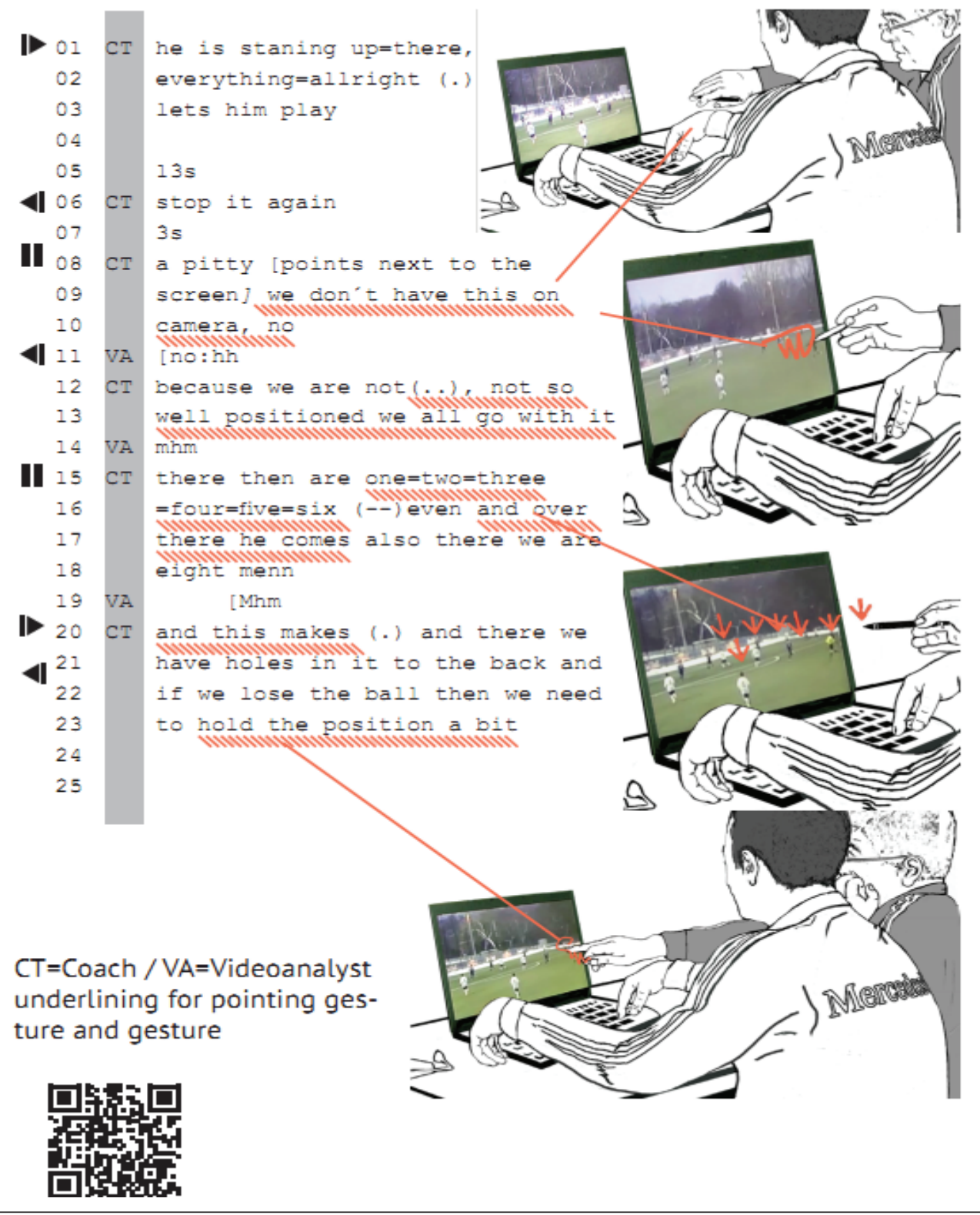

The coach refers to the video analyst's reconstruction of the event and rates it as "good". This is followed by a longer pause in which the advance to the opponent's goal is played again. Now the coach starts again with a "stop" prompt to which the video analyst reacts as usual with a short slow rewind of the video. Apparently there is something else in the clip that attracts attention again. Once again the coach complains that not the whole pitch is visible. But the faded out part seems to have a great relevance for him, so that this is explicitly addressed ("a pitty we don't have this on camera, no") 
and is confirmed by the video analyst. Here the interpretation suggests that knowledge about what is "behind" is somehow necessary to clarify the situation. In particular, it may be possible to close what "happens" at the back. Through the video sequence and his knowledge of the typical positions, the coach concludes the location of the two other players who are not visible in the video and presents them as imaginary. Similar to the video analyst before him, he achieves this performatively by drawing pointing gestures in the space next to the screen. So he expands the visible field into the "air" and relies on the video analyst to share this idea of a playing field. In this gesturelike imagination he begins to trace the visible (Streeck 2009:69) and continues this seamlessly next to the screen, where the artificially pristine space of the playing field is thereby continued. This imaginary representation is a solution to the fact that he can't simply show the players visually, which he expresses as a problem, because the screen is cut off here. Thus, he can reconstruct how many players are standing there, since this preparatory interpretation to illustrate the football tactics is prospectively designed to "show" the players something clearly later on. The coach and the analyst realize that they cannot simply demonstrate their actions to the players easily by showing an image. This relates to a more general issue that shows how the visualization serves not only to solve a technical problem, but highlights how professional knowledge is brought into the interpretation. It allows the coach to "extend" by imagination while evaluating what is objectively not visible. If only parts of the game are visible in the video, the coach will be able to anticipate what is happening in the back half. Based on his knowledge, he assumes with good reason, as most experienced footballers do, that the players behind him will also move forward (and not simply leave the field when they are not visible). He also illustrates this communicatively. Apparently, it is not necessary for him to always have a perspective in the video that covers the entire playing field in order to understand the game, because his consciousness is already constantly presenting the invisible. The space continues outside the represented video image and the players act for it in the mode of the idealized "and so on". Since the question of "what" happens in the non-visible, but in order to investigate how the distribution on the playing field is shaped is important, this must be reconstructed on the basis of cognitive conclusions, basal arithmetic operations (if eight are in front, only three can be behind): it is made accessible. This, actually cognitive operation, also takes place in the context of showing and materially bodily reference to the video that is running.

\section{Generalization}

In the last section (Fragment F3d) of the preparation of the illustration of this clip, which follows on from the previous ones, it now becomes clear, as the two analyzers did, that the reconstructed positioning is now based on a specific concept from the football language of positioning. This football term describes a tactically normatively good distribution of the players on the field in a certain situation (in attack) - it contrasts the problematic position on a line, which the coach calls here a 
dangerous scenario. He links this with a pointing gesture to the moment in the video, which is paused at a point where this is clearly visible. At the end of the sequence the problem is located - the coach draws the consequences from the distances that are considered problematic. The problem for him here is that too few players stay behind to catch balls that are played back from the penalty area due to running forward too fast. This means that the players cannot anticipate possible rebounds or balls returned by the opponent and therefore cannot use them for further attacks. On the contrary, the team may even be put in danger. The problem, the tactical weakness, or rather the mistake the team makes, becomes visible here: in the consequence, which is chronologically after the originally planned video.

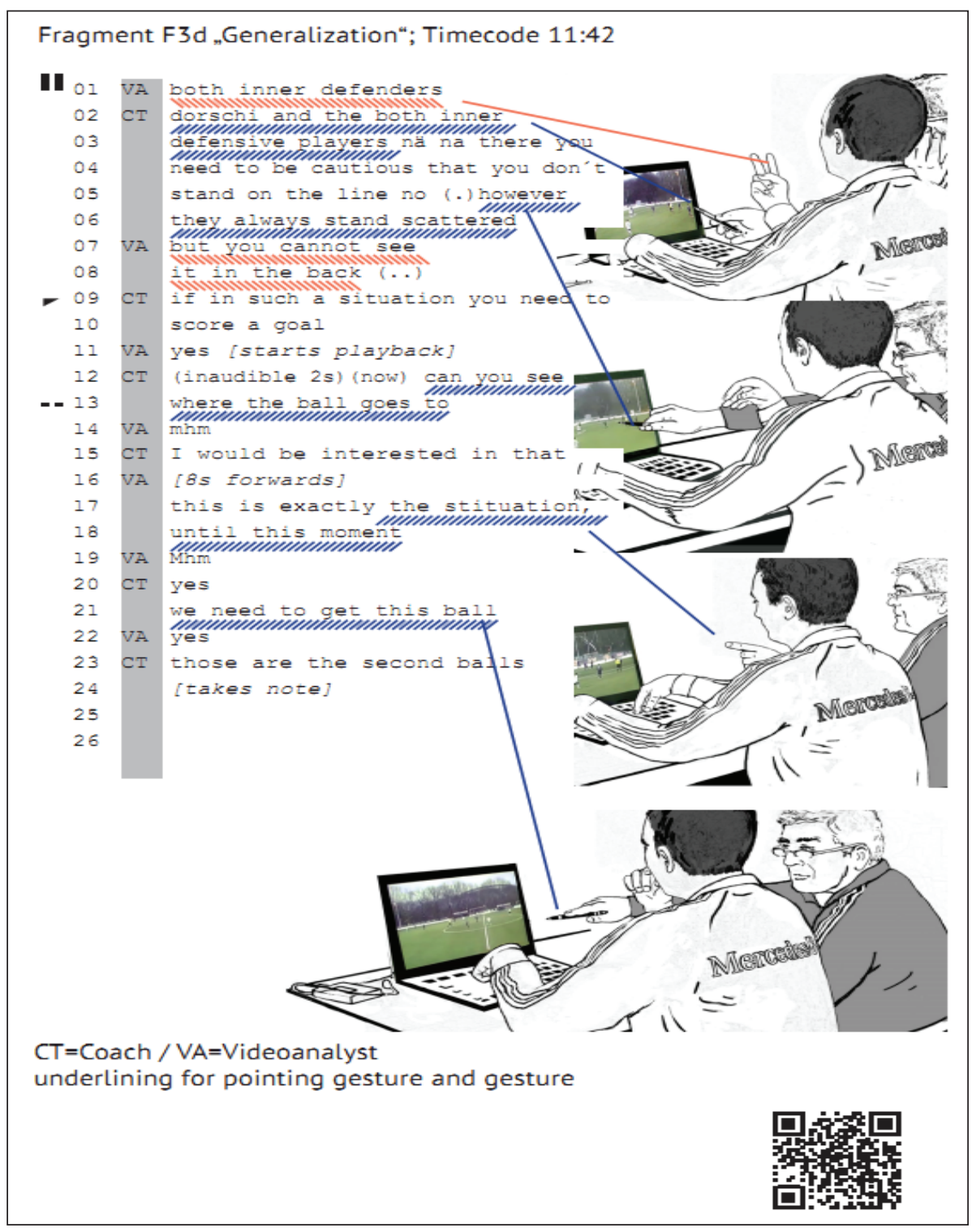


The analysis of this scene is concluded with the concluding statement of the coach "this is exactly the situation". "Until this moment" is an instruction to the video analyst to re-cut the clip, which they (invisible to us) also implement immediately. The coach summarizes his observation "we need to get this ball ... those are the second balls", and thus presents the observed individual case as a quintessential example, in which a typical situation ("second balls") is illustrated, which is later presented to the team as an example to give them a normative instruction for action. The coach ends this sequence by writing it down and by saying "that's enough, the scene is enough" in relation to the whole preparation session.

By this final communicative turns the preceding steps analysis are summarized and generalized. They are identified and crystallized as a key "topic" that is linked to the specific knowledge perspective of the trainer. In a process of communication, the still ephemeral observations are increasingly transform the recorded game as epistemic object (c.f. Rheinberger 1997, and for an overview Evenstein and Whyte 2009) into a specific objectivation of knowledge that is later used as a tool or rather a technical object. A striking visual example is produced that can later on be used and then unfolded again in interaction with the players.

In summary, the working process can follow the illustration in such a way; it is an interpretative treatment of systematically selected meaningful video recordings from a football match. The video analyst, based on his knowledge of football and the course of the match, has cut them out of the overall recording according to his relevance criteria (important decisions, clearly visible mistakes, special events), and now they are discussed together with the coach. Since this form of interaction is similar in many of its characteristics to video analysis in data sessions in sociology or other fields, it could be classified as "Video Analysis". However, here it is integrated into a very specific work arc which constitutes its specificity. In order to arrive at their results, the two have used the whole range of performative forms of visualization in their joint interpretation - as I have shown, from the marking and depiction of individual moments, relations and players, to the variation and presentation of possible consequences, to the connection with theoretical categories and established football knowledge. However, all these interpretive activities show a clear reference to the specific goal of didactic clarification of already known knowledge: the relevance of certain tactical maneuvers. The illustration is therefore not aimed at generating new, surprising insights, but at confirming known theories in a concrete case. In this case, it refers to the game and the whole team, even if individual players are also highlighted.

The players gather in the room afterwards, because after the preparation coaches and analysts want to give the team feedback on the (just evaluated) match of the previous evening as planned, which is based on the training aspect-i.e. learning how to implement game tactics more effectively. The preparation of the "inspection" that has just been carried out can thus be described as a special form of video analysis - inasmuch as the coach and the analyst generate specific detailed knowledge about the past football game in a communicative situation by reconstructing its course. However, the aim is not to create "new" knowledge about an unknown context, but 
rather to be able to illustrate the errors already suspected. Nevertheless, it is still possible to speak of the generation of new knowledge, because the two of them were not at all aware of some details in advance, and they developed more precise descriptions of the individual scenes and linked these with theoretical concepts (e.g. the second balls). The analyses are aimed at specific knowledge goals, which are embedded in an organisational context and a work arc (a training weekend) on the one hand, and in the field of football on the other hand through the institutionalised goals (winning matches and the conscious implementation of a game tactic, further development of promising young players etc.). In this case, the analysis also serves the purpose of research into the origins, whereby this is in turn "overlaid" by its function - training and the following instruction. The next sequence shows how the "interpretation contents" of the sequence are then resumed in the instruction. The individual sequences are not only evaluated for their own sake, but the sequences are rather processed in such a way that the coach and the video analyst can present the findings as examples of problems. The products of the interpretation are then commentable clips - which can be used in the presentation as a revealing document with an evidential character of a certain problem or to legitimize a certain tactical component, which is also embedded in a theoretical context.

At the end of the discussion of the individual sequences, the coach and video analysts go through all the clips once again and make a detailed selection of what they will present afterwards. They prefer those scenes in which the problems of the game they have identified become evident in a compact and demonstrative way, which they comment on again when playing the clips.

\section{Summary}

It still remains to be seen whether video analysts will be able to establish themselves as a profession in their own right in this field, or whether it will remain with a few prominent personalities visible in the media. Currently, video analysts are doing their job well shielded and invisible in support of the coaches. However, they are - and this is only visible from "inside" - communicatively involved in the interpretation, and actively participate in making the phenomena visible.

Video analysis is used to inform the planned strategy of the coach, but it is above all also part of the work with the team, which for coaches is communication. Video analysis is not only used as a source of knowledge, but is also introduced into didactically framed situations, in which the coaches integrate a whole range of requirements, from the transfer of tactical knowledge, to the motivation of their own team and the implementation of long-term theoretically specific training concepts (c.f. the ethnography of Schilling 2001:337ff). However, the video serves as a source for detailed reconstructions of individual sequences, in which specific new insights are generated, as well as for the legitimizing illustration of game theoretical concepts, which are presented to the players in a normative way. In concrete terms, this is primarily a matter of tactical concepts, which consist above all of a certain idea of 
the playing field. The playing field is presented as a dynamic space and the players receive instructions for action in certain situations. They are supposed to internalize certain arrangements, play patterns and maneuvers in order to be successful.

The interpretations of observed segments of the data are transformed into prospective instructions, which must then be presented in situ - either a form of re-enactment or the tactical board comes into play. The didactic situation between coaches and players therefore always involves two things: the recourse to the sometimes erroneous past and the positive transformation of the mistakes in the future, which can sometimes lead to the creation of rules of action. The work arc is thus again embedded in various dimensions of temporality that extend beyond the respective training weekend. In conclusion, it can be clarified once again that current professional ball does not last 90 minutes, but that the game has long since been extended to include preliminary discussions, debriefings, analyses of other teams, etc., which a coach carries out with his team. In doing so, he has access to a large number of co-operating specialists (from sports psychologists to athletics coaches and video analysts) who work in the background to accelerate the game.

The special focus of the empirical case study lies not only on the empirical recording of an empirical phenomenon (i.e. the video work), but also on the theoretical embedding of the research design in the study itself. The strength of communicative constructivism lies in placing the phenomena that are often the focus of interest in studies of social situations, the individual courses of action and sequences, the bodies and objects and the practices, forms and communicative genres that can be identified from them in a broader context. Through processes of institutionalizing work activities (here the formation of work arcs), the establishment of new knowledge bases from concrete actions and communicative work practices, experts establish themselves, organizations are founded and fields are established. Material objectivations also ensure durability, but must be constantly reinterpreted. This view guides the study, and enables a more precise, processual understanding of the communicative processes of the communicative construction of reality. Thus, my study is not only designed to learn something about an esoteric special field of knowledge - the world of video analysts or sports coaching - but it is more comprehensively about an understanding of the communicative processes of interpreting audiovisual data in general. As I have explained, showing and interpreting are communicative actions, and interpretation is much more than just a purely cognitive process of individuals. Furthermore, my study is reflexive because it deals with the communicative interpretation of videos, i.e. what I have done myself for research purposes. A more precise, in the narrow sense reflexive empirical investigation of social science methods is still in its infancy, but my work on "Vernacular Video Analyses" is a foil with which other sociological video analyses can be contrasted. 


\section{Literature}

Boehm, Gottfried. 1994. 'Die Wiederkehr der Bilder'. Pp. 11-38 in Was ist ein Bild?, edited by G. Boehm. München: Fink, Wilhelm.

Ewenstein, Boris, and Whyte, Jennifer. (2009). Knowledge Practices in Design: The Role of Visual Representations as 'Epistemic Objects'. Organization Studies 30(1): 07-30.

Gerson, Elihu M. 1983. 'Work and Going Concerns: Some Implications of Hughes' Work'. Presented at the 'Theoretical Implications of E.C. Hughes' work' at the meeting of the Pacific Sociological Association', San Jose.

Heath, Christian, Jon Hindmarsh, and Paul Luff. 2010. Video in Qualitative Research: Analysing Social Interaction in Everyday Life. London: Sage.

Heath, Christian, and Paul Luff. 2000. Technology in Action. Cambridge: Cambridge University Press.

Heath, Christian, Marcus Sanchez Svensson, Jon Hindmarsh, Paul Luff, and Dirk vom Lehn. 2002. 'Configuring Awareness'. Computer Supported Cooperative Work (CSCW) 11(3-4): 317-47.

Knoblauch, Hubert. 2019. The Communicative Construction of Reality. Milton Park, Abingdon, Oxon ; New York, NY: Taylor \& Francis Ltd.

Knoblauch, Hubert, René Tuma, and Bernt Schnettler. 2013. 'Video Analysis and Videography'. in Sage Handbook of Qualitative Data Analysis, edited by U. Flick. London: Sage.

Lames, Martin. 2013. 'Videotaktiktraining - Unausgeschöpfte Potentiale'. in Neue Trends bei der EURO 2012 : Entscheidungskompetenz in Abwehr und Angriff / Internationaler Trainer-Kongress 2012, edited by S. Groß and T. Voggenreiter. Frankfurt, M.: BDFL.

Laurier, Eric, Ignaz Strebel, and Barry Brown. 2008. 'Video Analysis: Lessons from Professional Video Editing Practice'. Forum Qualitative Sozialforschung / Forum: Qualitative Social Research 9(3).

Luff, Paul, Christian Heath, and Marcus Sanchez Svensson. 2008. 'Discriminating Conduct: Deploying Systems to Support Awareness in Organizations'. International Journal of Human-Computer Interaction 24(4): 410-36.

Luhmann, Niklas. 1997. Die Gesellschaft Der Gesellschaft. Frankfurt am Main: Suhrkamp.

Mair, Michael (Author), Chris (Author) Elsey, Paul V. (Author) Smith, and Patrick G. (Author) Watson. 2018. 'War On Video: Combat Footage, Vernacular Video Analysis And Military Culture From Within'.

Martin, R. Bruce. 1999. 'A Genealogy ofBiomechanics'. in 23rd Annual Conference of the American Society of Biomechanics. University of Pittsburgh. 
Mitchell, W. J. T. 2005. What Do Pictures Want?: The Lives and Loves of Images. Chicago: University of Chicago Press.

Mitchell, William JT. 1997. 'Der Pictorial Turn'. Pp. 15-40 in Privileg Blick. Kritik der visuellen Kultur, edited by C. Kravagna. Berlin: ID-Verlag.

Perry, Mark, Oskar Juhlin, and Arvid Engström. 2014. 'Dealing with Time, Just In Time: Sense-Making and Clip Allocation in Multiperson, Multistream, Live Replay TV Production'. Pp. 262-86 in Studies of video practices: video at work, edited by M. Broth, E. Laurier, and L. Mondada. New York: Routledge.

Reichertz, Jo, and Carina Englert. 2010. Einführung in die qualitative Videoanalyse: Eine hermeneutisch-wissenssoziologische Fallanalyse. Wiesbaden: VS Verlag für Sozialwissenschaften.

Rheinberger, Hans-Jörg. 1997. Toward a History of Epistemic Things: Synthesizing Proteins in the Test Tube. Writing Science. Stanford, Calif: Stanford University Press.

Schilling, Marcel. 2001. Reden und Spielen: die Kommunikation zwischen Trainern und Spielern im gehobenen Amateurfussball. Tübingen: Gunter Narr Verlag.

Schmidt, Robert, and Basil Wiesse. 2019. 'Online Participant Videos: A New Type of Data for Interpretative Social Research?' Forum Qualitative Sozialforschung / Forum: Qualitative Social Research 20(2).

Streeck, Jürgen. 2009. Gesturecraft the Manu-Facture of Meaning. Amsterdam etc.: John Benjamins Pub.

Tomasello, Michael. 2009. Die Ursprünge Der Menschlichen Kommunikation. Frankfurt am Main: Suhrkamp.

Tuma, René. 2017. Videoprofis Im Alltag - Die Kommunikative Vielfalt Der Videoanalyse. Wiesbaden: Springer VS.

Wilson, Jonathan, and Markus Montz. 2011. Revolutionen auf dem Rasen eine Geschichte der Fußballtaktik. Göttingen: Verl. Die Werkstatt.

Рене Тума

\section{ПРОФЕСИОНАЛНА ИНТЕРПРЕТАЦИЈА У СПОРТСКОМ ТРЕНИНГУ - АНАЛИЗА КОМУНИКАТИВНИХ ПРАКСИ СВАКИДАШЫЕ ВИДЕО-АНАЛИЗЕ}

Ancтракт: Овај рад се бави комуникацијским праксама и визијом стручњака. Показује да тумачење видео снимака није чисто когнитивно, већ је континуирано комуникативно постигнуће. На основу анализе видео снимака и етнографских истраживања, анализа показује како сами професионалци у спортском тренингу користе аудио-визуелне податке за стварање знања. Анализа се заснива на 
теоријској позадини комуникативног конструктивизма и бави се употребом технологије од стране учесника, ситуацијским телесним изведбама које чине ствари видљивим и локалном производњом знања као комуникативне праксе. Специфични облици показују карактеристике локалних култура „вернакуларне/ свакидашње видео анализе“. Док рад наглашава ситуационе аспекте чина интерпретације, он их у исто време поставља у шири оквир делања специфичног за одређену област.

Кључне речи: визуелни подаци, вернакуларна/свакидашња видео-анализа, комуникативне праксе, телесне изведбе, локална производња знања 